\title{
Selection of scFv Phages on Intact Cells Under Low pH Conditions Leads to a Significant Loss of Insert-Free Phages
}

BioTechniques 30:404-413 (February 2001)

\author{
M.K. Tur, M. Huhn, S. Sasse, \\ A. Engert, and S. Barth \\ University of Cologne, \\ Cologne, Germany
}

\begin{abstract}
Display of functional antibody fragments on the surface of filamentous bacteriophages allows fast selection of specific phage antibodies against a variety of target antigens. However, enrichment of single chain variable fragment ( $s c F v$ )-displaying phages is often hampered by the abundance of bacteriophages lacking antibody fragments. Moderate adhesive binding activities and production advantages of these "empty" phages results in their subsequent enrichment during selection on target cells. To date, very limited effort has been made to develop strategies removing nonspecific binding phages during the selection processes. To efficiently reduce insert-free phages when panning on intact cells, we increased the washing stringency by lowering the $\mathrm{pH}$ of the buffer with citric acid. Under standard washing procedures ( $\mathrm{pH} 7.4$ ), only approximately $73 \%$ of recovered phages were insert-free after three rounds of selection. Using stringent washing procedures (pH 5.0), approximately $12 \%$ of recovered phages contained no $s c F v$. Using this protocol, we have cloned an antibody fragment from a mouse/human hybridoma cell line directed against the disialoganglioside $G_{D 2}$. This study confirms that selection of phage antibodies on cells is efficiently enhanced by assays augmenting the stringency to remove nonspecific binding phages.
\end{abstract}

\section{INTRODUCTION}

Despite encouraging results in the last decade, it still remains a major task to design new immunotherapeutics against different forms of human cancer. Phage display technology represents a potential tool to identify new binding structures $(17,36)$. Antibody fragment-displaying phage libraries are created by amplifying immunogolobulin V genes via PCR and cloning of the assembled $V_{H}$ and $V_{L}$ genes into phagemid vectors. After transfection into E. coli, bacteriophages are produced expressing functional antibody fragments fused to a minor coat protein [i.e., minor coat protein III (gpIII)]. The expression of this fusion gene at the surface of phages allows the enrichment of specific binding phage by selection on purified antigen or on cell surfaces (15). One of the major obstacles in phage display technology is the contamination of antibody phage libraries with antibody fragment-free vectors $(3,8,10,22,33)$, resulting in a failure to enrich specific binding phages. This effect is based on (i) incomplete restriction and/or self-ligation of the phagemid during cloning of the antibody phage library and (ii) the generation of recombinant phages by helper phagedependent packaging of phage particles (16) during phage rescue in very low efficiency. Thus, the majority of rescued phage expresses only native gpIII, which causes enrichment of these phages based on their nonspecific adhesive binding activity to any antigen $(24,25)$. Furthermore, the reduced vec- tor size impairs enrichment of specific phage (22), resulting in a growth advantage of the insert-free phages.

Strategies dealing with the reduction of the number of insert-free phage are very limited. Phagemid vectors were modified with the intention to address these problems. To monitor the efficiency of complete vector restriction during cloning, a tetracycline resistance cassette was inserted between the restriction endonuclease sites of a phagemid vector (22). An antibiotic resistance encoding gene was cloned as an in-frame fusion with the single chain variable fragment $(\mathrm{scFv})$ to eliminate deleted clones from the library (32), and an affinity tag was inserted at the $3^{\prime}$ end of the scFv to enable an enrichment of phages from the culture supernatants (3). Reliable inducible promoters and helper phages with gene III deletion are in development $(14,31)$, which would theoretically increase the quality of antibody phage libraries.

In standard protocols for the selection of phage antibodies $(22,26)$, nonspecific binding phages are removed from target antigen by washing with PBS containing $0.1 \%$ Tween $^{\circledR} 20$ (TPBS) at $\mathrm{pH}$ 7.4. Specific phages are then eluted and used to reinfect $E$. coli. However, very stringent elution conditions, which are probably necessary due to the high affinity of the $\mathrm{scFv}$ phages $(9,30)$, were recently described to retrieve all phages. Most of the recovered phages are insert-free, which indicates that these phages remain attached to the cell as a result of inadequate washing procedures. Thus, we 
reasoned that it might be possible to reduce the amount of insert-free phages during selection by simply increasing the washing stringency. This approach was documented by isolating a phage antibody from a human/mouse chimeric hybridoma cell line, ch14.18 (12), directed against the disialoganglioside G2. In the present study, insert-free and low-affinity phage antibodies were significantly minimized by lowering the $\mathrm{pH}$ of the washing buffer, maximizing the chance of isolating specific binders from a background of irrelevant $(3,6)$ phagemid particles.

\section{MATERIAL AND METHODS}

\section{Cell Lines and Cell Culture}

The human neuroblastoma cell line IMR5 was obtained from Dr. Unwicker (Institution of Cell Biology and Neuroanatomy, University of Marburg, Germany); the human/mouse chimeric anti-G $\mathrm{G}_{2}$ hybridoma cell line was provided by Dr. Reisfeld (Scripps Clinic, La Jolla, CA, USA); and the G2-negative Hodgkin-derived cell line L540Cy (19) was cultivated in RPMI 1640 (Life Technologies, Rockville, MD, USA) supplemented with $10 \%$ (v/v) heat-inactivated fetal calf serum (FCS), 50 $\mu \mathrm{g} / \mathrm{mL}$ penicillin, $100 \mu \mathrm{g} / \mathrm{mL}$ streptomycin, and $2 \mathrm{mM}$ L-glutamine (all from Life Technologies). All cells were cultured at $37^{\circ} \mathrm{C}$ in a $5 \% \mathrm{CO}_{2}$ atmosphere. Growth medium was changed every three days, and cells were subcultured twice weekly.

\section{Membrane Preparations of Tumor Cells}

IMR5 and L540Cy cells $\left(1 \times 10^{7}\right.$ each) were suspended in $10 \mathrm{~mL}$ PBS, $\mathrm{pH} 7.4$, and washed three times with PBS by repetitive resuspension and centrifugation at $200 \times g$ for $10 \mathrm{~min}$. The pelleted cells were suspended in 5 $\mathrm{mL}$ ice-cold $25 \mathrm{mM}$ Tris- $\mathrm{HCl}$ buffer, $\mathrm{pH} 7.4$, containing $320 \mathrm{mM}$ sucrose. A protease inhibitor tablet (Complete $^{\mathrm{TM}}$, Roche Molecular Biochemicals, Mannheim, Germany) was added to the suspension, and membrane fractions were prepared by sequential, low-frequency sonication (Model HD 2070, Sonoplus,
Berlin, Germany) at 9 kcycles/s for three time intervals $(3,1.5$, and 1.5 $\min )$ at $0^{\circ} \mathrm{C}$. Interruption time was 1 min after each time interval. The homogenate was centrifuged at $1000 \times g$ for $12 \mathrm{~min}$ at $4^{\circ} \mathrm{C}$ to remove unbroken cells, nuclei, and cell debris. The supernatant was removed and centrifuged at $100000 \times \mathrm{g}$ for $20 \mathrm{~min}$ at $4^{\circ} \mathrm{C}$. The resulting cell membrane (CM) pellet was suspended in $5 \mathrm{~mL} 50 \mathrm{mM}$ Tris- $\mathrm{HCl}$ buffer, $\mathrm{pH}$ 7.4, and centrifuged at $100000 \times g$ for $20 \mathrm{~min}$ at $4{ }^{\circ} \mathrm{C}$ to remove loose-bound proteins from the mem brane surface. The supernatant was discarded, and the CM pellet was finally suspended in $1.2 \mathrm{~mL} 0.02 \mathrm{M}$ bicarbonate buffer, $\mathrm{pH}$ 9.6, and stored in aliquots at $-80^{\circ} \mathrm{C}$ until analysis. The protein concentrations of individual membrane preparations were determined spectrophotometrically using the DC-Protein Assay Kit (Bio-Rad Laboratories, Munich, Germany) with BSA (Sigma, Deisenhofen, Germany). Typical yields ranged between 0.8 and 1.0 $\mathrm{mg}$ protein $/ \mathrm{mL}$.

\section{Construction of a Hybridoma- Derived Recombinant Phage Antibody Library}

Total RNA was isolated from $1 \times$ $10^{7}$ ch14.18 cells using the RNeasy ${ }^{\circledR}$ Kit (Qiagen, Hilden, Germany) according to the manufacturer's instructions. About $10 \mu \mathrm{g}$ total RNA was reverse transcribed in a reaction volume of 33 $\mu \mathrm{L}$ using oligo(dT) primer and moloney murine virus reverse transcriptase according to the manufacturer's protocol (Amersham Pharmacia Biotech, Freiburg, Germany). Immunoglobulin variable genes were PCR-amplified using degenerated primers complementary to immunoglobulin framework region one and joining segments based on sequence data extracted from the Kabat database (18). V gene coding regions were amplified from $0.5 \mu \mathrm{L}$ firststrand cDNA and assembled to scFv by splicing by overlap extension (SOE)PCR (4) inserting a $\left(\mathrm{Gly}_{4} \mathrm{Ser}\right)_{3}$ linker. After reamplification to introduce an $S f i$ restriction site at the $5^{\prime}$ end and at the $3^{\prime}$ end a NotI site (for cloning into the vector), the fragments were purified by agarose gel electrophoresis and digested with the same restriction en- zymes. Digested fragment (100 ng) was used for ligation with $150 \mathrm{ng}$ SfiI/Not Ilinearized pCANTAB', a derivative of pCANTAB6 (28) with a new multiple cloning site (Figure 1). The ligation reaction was purified by phenol extraction and electroporated into $50 \mu \mathrm{L}$ electrocompetent $E$. coli TG1 cells (Stratagene, La Jolla, CA, USA) and incubated overnight at $30^{\circ} \mathrm{C}$.

\section{Selection of Specific Phage by Stringent Washing Procedure}

The hybridoma-derived phage antibody library was constructed as previously described (5). After phage rescue, selection was performed using a cell panning procedure (35). Recombinant phage $\left(10^{6}-10^{8}\right)$ and $1 \times 10^{7}$ IMR5 cells were separately blocked with $4 \%$ skimmed milk in PBS for 30 min at room temperature or $24^{\circ} \mathrm{C}$. Preabsorbed phage solution was added to the cells, and the mixture was incubated for $1 \mathrm{~h}$ at room temperature. Nonspecific phages were removed under standard conditions by washing the cells 20 times with $5 \mathrm{~mL}$ washing buffer TPBS at pH 7.4, centrifuged at $500 \times g$ for $4 \mathrm{~min}$, resuspended, and gently vortex mixed further for $15 \mathrm{~s}$. In parallel, cells were washed 15 times with TPBS at pH 7.4 and subsequently five times with TPBS at $\mathrm{pH} 5.0$, adjusted by $76 \mathrm{mM}$ citric acid, centrifuged at $600 \times g$ for $2 \mathrm{~min}$, resuspended, and vortex mixed. Finally, samples were washed five times with PBS only and transferred into a fresh tube. After centrifugation, cells were resuspended in $76 \mathrm{mM}$ citric acid and incubated for 10 min at room temperature. Eluted phages were finally neutralized separately after centrifugation by transfer of the supernatant to an equal volume of 1 $\mathrm{M}$ Tris- $\mathrm{HCl}$ at $\mathrm{pH} 7.5$ and were used to infect logarithmically growing $E$. coli TG1 cells. Infected cells were grown overnight at $30^{\circ} \mathrm{C}$ on $2 \times \mathrm{YT}_{\mathrm{GA}}$ agar plates (16 g tryptone, $10 \mathrm{~g}$ yeast extract, $5 \mathrm{~g} \mathrm{NaCl}$, and $15 \mathrm{~g}$ agar/L) containing $2 \%(\mathrm{w} / \mathrm{v})$ filter-sterilized glucose and $100 \mu \mathrm{g} / \mathrm{mL}$ ampicillin. The selection procedure was repeated three times. Retrieved phages were analyzed by scFv-insert amplification and phage ELISA using CM preparations (CMELISA). 


\section{Phage ELISA on Membrane Preparations}

CM-ELISA was performed using ELISA microplates coated with freshly prepared membrane fractions of IMR5 cells and L540Cy as control and stored (until 10 months) at $-80^{\circ} \mathrm{C}$. MaxisorpPlates (96-well; Nalge Nunc International, Roskilde, Denmark) were coated with $100 \mu \mathrm{L}$ CMs (approximately 0.9 $\mathrm{mg}$ protein $/ \mathrm{mL}$ ) in $0.02 \mathrm{M}$ bicarbonate buffer, $\mathrm{pH} 9.6$, overnight at $4^{\circ} \mathrm{C}$. Plates were washed five times with TPBS and blocked with $200 \mu \mathrm{L} 2 \%$ BSA in PBS (PBSA). After overnight incubation at $4^{\circ} \mathrm{C}$, binding of the selected library (polyclonal phage ELISA) and of randomly picked singular phages (monoclonal phage ELISA) were detected (34) using peroxidase-conjugated antiM13 antibodies (Amersham Pharmacia Biotech) after addition of $100 \mu \mathrm{L} 2^{\prime}, 2^{\prime}$ azino-bis(3-ethylbenzthiazoline-6-sulphonic acid) $\left(\mathrm{ABTS}^{\circledR}\right.$ ) solution (Roche Molecular Biochemicals) by measuring the extinction at $415 \mathrm{~nm}$ with an ELISA-Reader (MWG Biotech, Ebersberg, Germany).

\section{Insert Amplification and DNA Fingerprinting}

The quality of the library and the efficiency of the washing procedure were monitored after each round of selection by PCR amplification of the scFv insert from the phagemid vector of randomly picked clones using the primers pucRev (5'-CAGGAAACAGCTATGAC-3') and fdtet (5'-TTTGTCGTCTTTCCA GACGTTAGT-3') in 30 cycles at $94^{\circ} \mathrm{C}$ for $1 \mathrm{~min}, 55^{\circ} \mathrm{C}$ for $1 \mathrm{~min}$, and $72^{\circ} \mathrm{C}$ for $1.5 \mathrm{~min}$, followed by an extension at $72^{\circ} \mathrm{C}$ for $10 \mathrm{~min}$. Following the third round of panning, 34 randomly picked clones of the selected library, which were positive in polyclonal and monoclonal CM-ELISA, were individually tested for diversity by digestion of the amplification product with the frequent-cutting enzyme HaeIII as described previously (35).

\section{RESULTS AND DISCUSSION}

In this study, we report the reduction of $\mathrm{scFv}$-free phages during selection of a ch14.18-derived phage antibody library on the neuroblastoma cell line, IMR5. The major findings to emerge from our study are: $(i)$ lowering the $\mathrm{pH}$ of the washing step significantly reduced the proportion of insert-free phages nonspecifically enriched during the bio-panning procedure; (ii) selected anti-G $\mathrm{G}_{2}$ phage antibodies were easily identified on functional membrane preparations of IMR5 cells by cellmembrane ELISA; and (iii) the titration of the phage input/output ratio for each round of selection (35) and the polyclonal phage ELISA with the selected library (22) are limited in documenting the enrichment of specific binding phages. These methods only become reliable after deletion of nonspecific binding activities of insert-free phages.

Our group is developing new im munotherapeutic strategies for the treatment of Hodgkin's disease and malignant lymphoma. Using phage display technology and chain shuffling, we generated both murine (20) and human anti-CD30 scFv (21) by enrichment of hybridoma-derived mini-libraries on the Hodgkin-derived cell line L540Cy. After genetic fusion of the se- lected $\mathrm{scFv}$ to a deletion mutant of Pseudomonas exotoxin A (27), efficient antitumor activity was documented in vitro and in vivo (2).

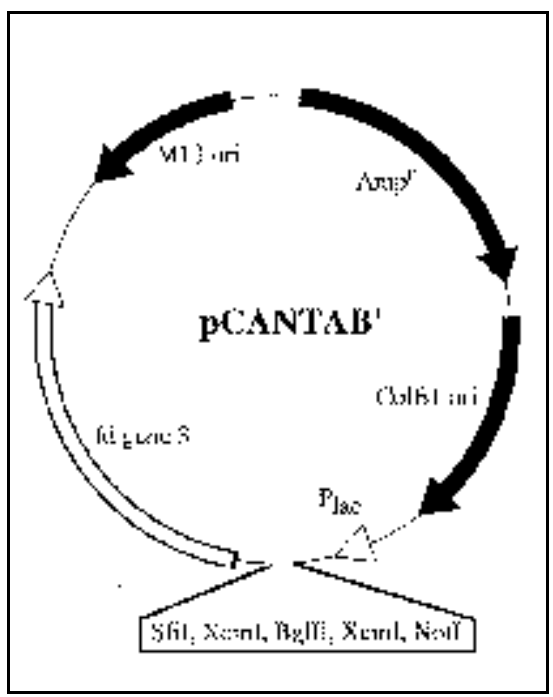

Figure 1. Constructed pCANTAB6 derivative with modified multiple cloning site for TA cloning after $\mathrm{XcmI}$ digestion. The plasmid contained the gene III expression module, an ampicillin resistance gene $\left(\mathrm{Amp}^{\mathrm{r}}\right)$, an $E$. coli origin of replication (ori) (pBR322 ori), an M13 ori, and the lac promoter $\left(\mathrm{P}_{\mathrm{lac}}\right)$.

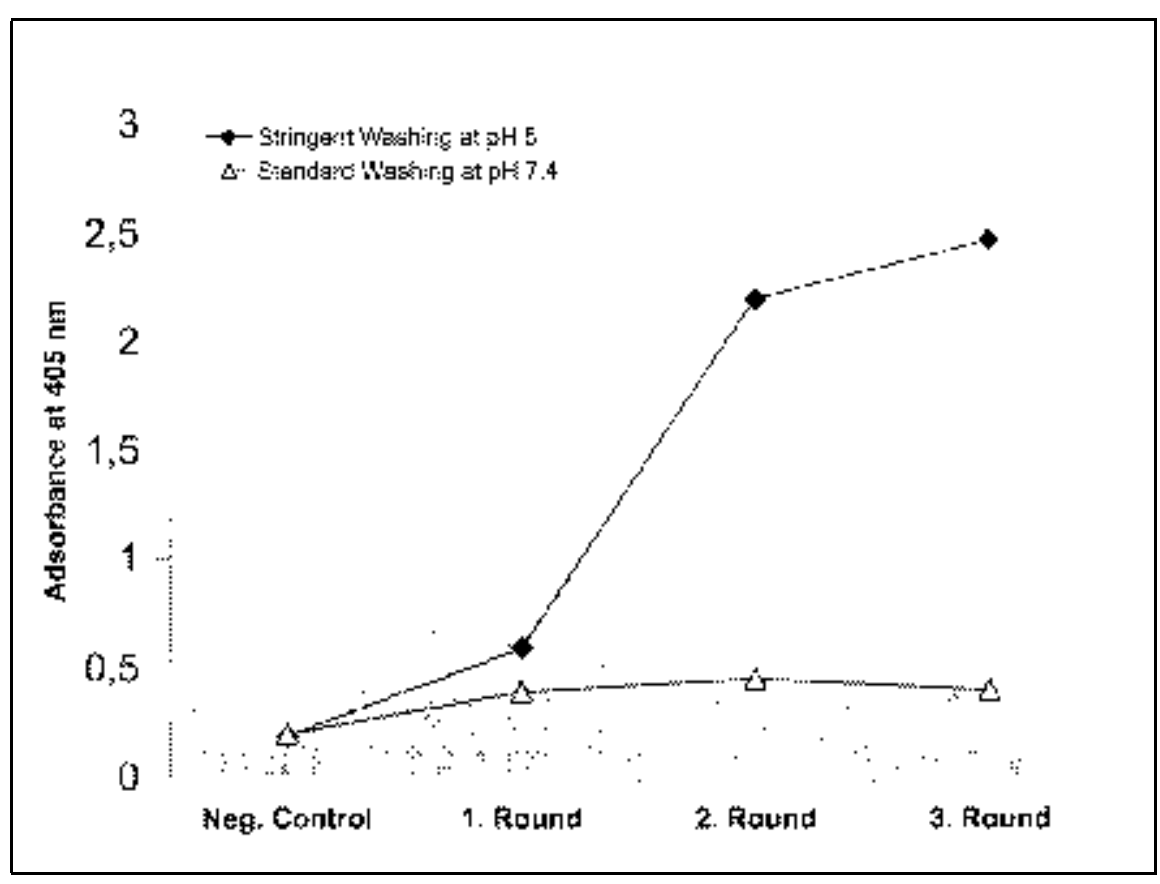

Figure 2. Selective enrichment of phages at different conditions of phage washing documented by polyclonal CM-ELISA. Phage pools (approximately $1.5 \times 10^{1} 0 \mathrm{cfu} /$ well) prepared after 1, 2, and 3 rounds of panning over the neuroblastoma cell line IMR5 under standard (pH 7.4) and stringent (pH 5.0) washing conditions were tested for specific binding on membrane fractions of G2-positive IMR5 cells in a polyclonal phage ELISA. M13KO7 helper phages were used for negative control. 


\section{Research Report}

A

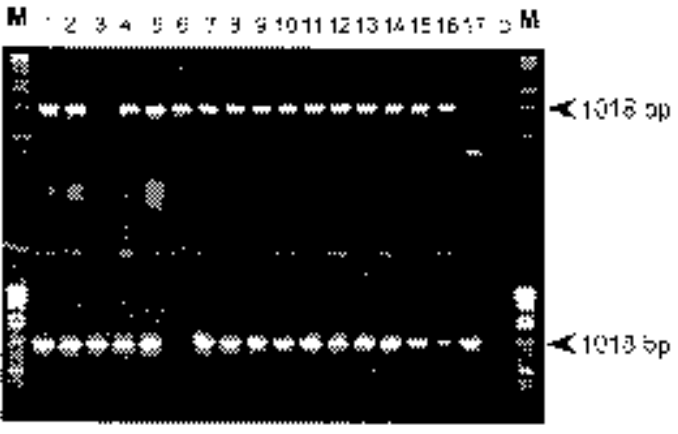

16

$3+5$

C

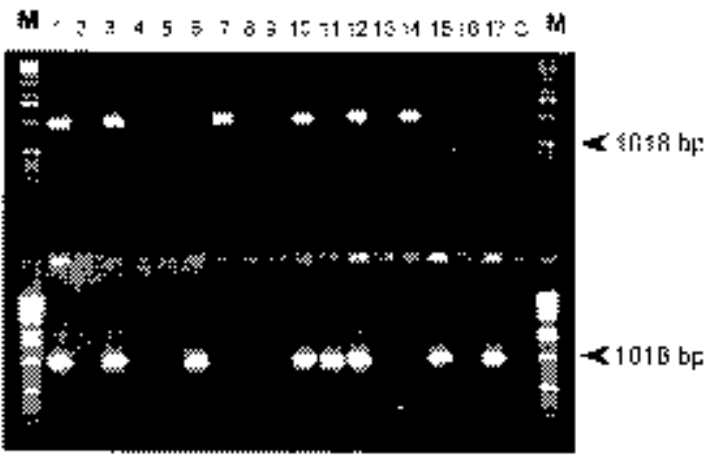

18

$\because C$

$\mathbf{E}$

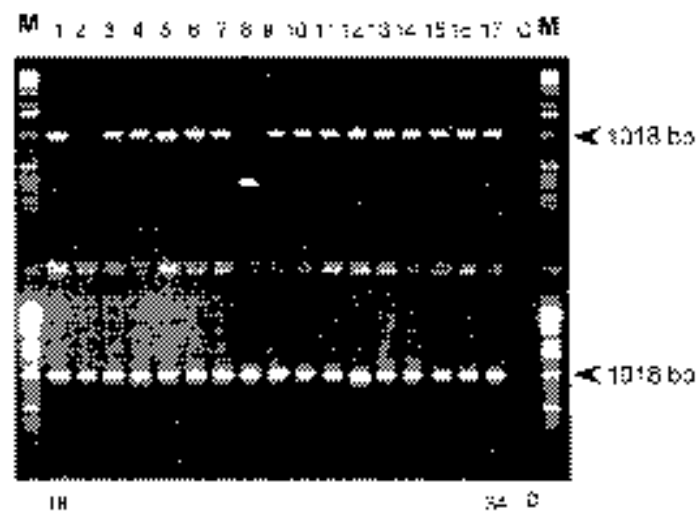

G.

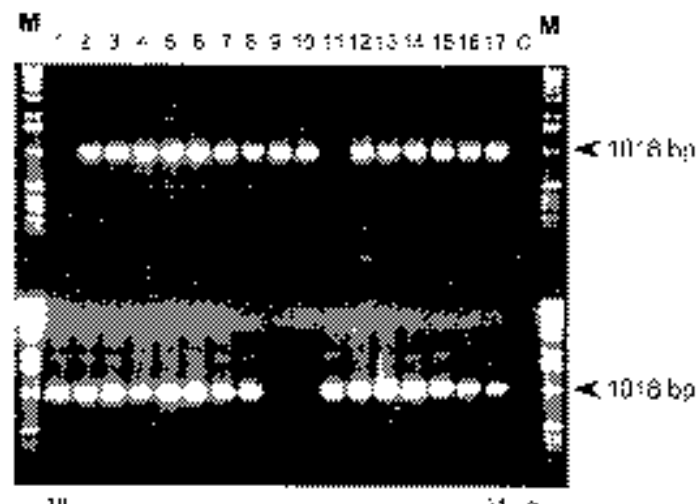

B

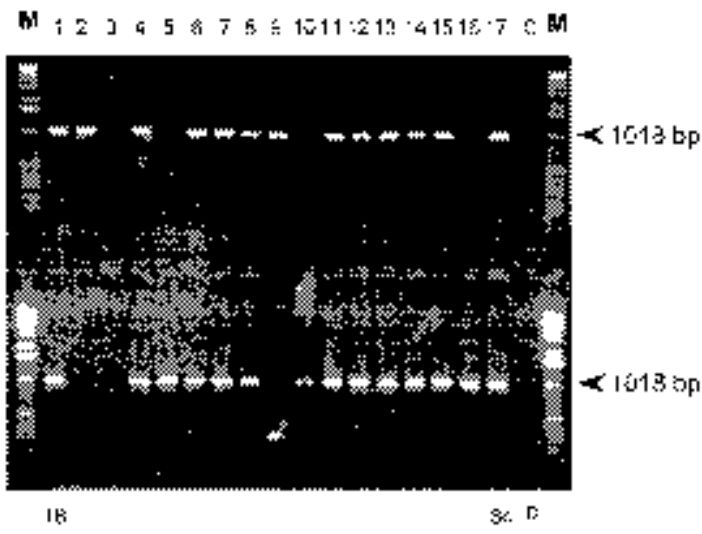

D

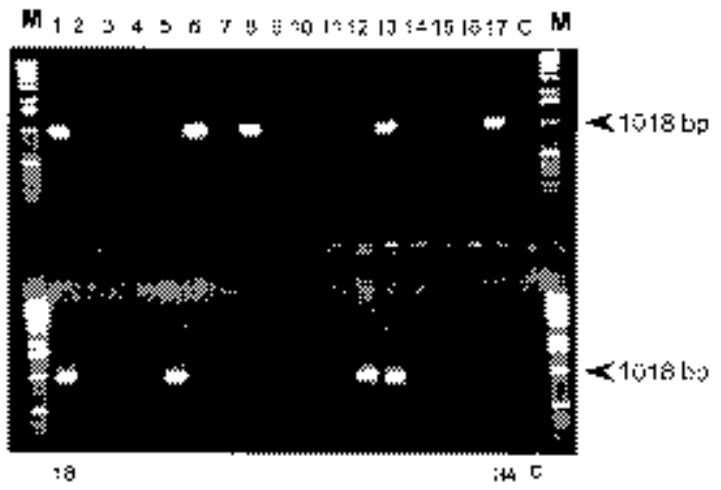

F

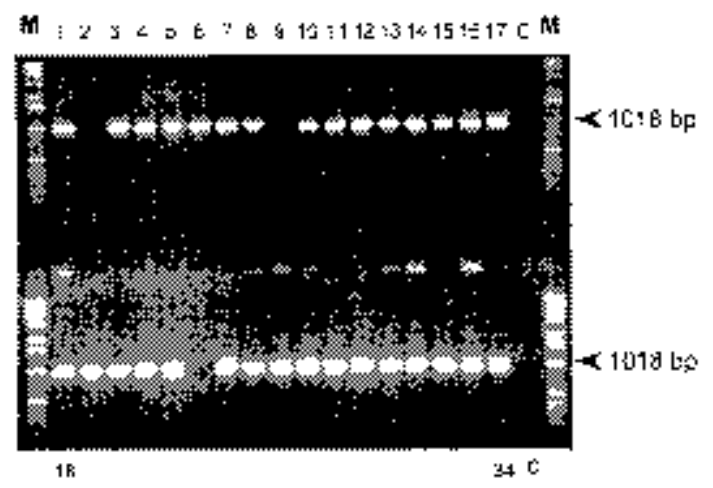

Figure 3. PCR analysis of scFv inserts of randomly picked clones from the ch14.18-derived phagemid mini-library after each round of panning on the neuroblastoma cell line IMR5. (A) Original library; (B) first selection after washing in TPBS, $\mathrm{pH}$ 7.4; (C) second selection after washing in TPBS, $\mathrm{pH}$ 7.4; (D) third selection after washing in TPBS, pH 7.4; (E) first selection after washing in TPBS, pH 5.0, adjusted with $76 \mathrm{mM}$ citric acid; (F) second selection after washing in TPBS, $\mathrm{pH}$ 5.0; and (G) third selection after washing in TPBS, $\mathrm{pH}$ 5.0. PCRs generated with primers pucRev and fdtet were analyzed after electrophoresis in ethidium bromide-stained $1 \%$ agarose gels. c, water controls; M, molecular size standard (1-kb ladder; Life Technologies). 


\section{Research Report}

In the present study, phage display was used to construct a new scFv minilibrary from the human/mouse chimeric anti-G $\mathrm{G}_{2}$ hybridoma. A strong enrichment of specific binding phages was detected during sequential rounds of panning on the neuroblastoma cell line IMR5 at stringent ( $\mathrm{pH}$ 5.0) selection conditions. However, no enrichment was found under standard (pH 7.4) panning conditions. These data were confirmed by determination of the input/ output ratio during the panning procedure. Using an input of $1.3 \times 10^{10}$ phage at each round of selection, the output was $2.3 \times 10^{4}$ after the first round, $8.5 \times$ $10^{6}$ after round two, and $9.6 \times 10^{6}$ after three rounds of panning under stringent conditions. Thus, there was an enrichment of about 420 -fold between the first and third round of panning. Under standard panning conditions, phage output after the first round was comparable to the amounts documented under stringent conditions but decreased during successive panning (Table 1). The binding activity of the selected phage antibodies was documented by a newly established CM-ELISA facilitating the functional screening of the bacteriophages. Membrane preparations coated to plastic surfaces were highly stable during intensive washing procedures without loss of function. The described input/output data directly correlate to the polyclonal phage ELISA (Figure 2). Insert-free phages (approximately $73 \%$ ) were found under standard washing conditions ( $\mathrm{pH}$ 7.4) after three rounds of selection on the neuroblastoma cell line IMR5 in comparison to the original library (Figure 3 ). The insert-free phages documented by this PCR were confirmed by restriction analyses of the phagmids prepared from these clones. Several conditions for the elution of phage antibodies from target antigens, including $\mathrm{HCl}$ (1), triethylamine (26), and citric acid (23) have been published. Prolonged elution time with triethylamine resulted in a high percentage of high-affinity phage antibodies (9). To increase the stringency of the washing procedure, we compared the abovementioned elution agents (data not shown). The best results were observed using $\mathrm{pH} 5.0$ titrated by citric acid. The percentage of nonspecific binding phages was significantly reduced to

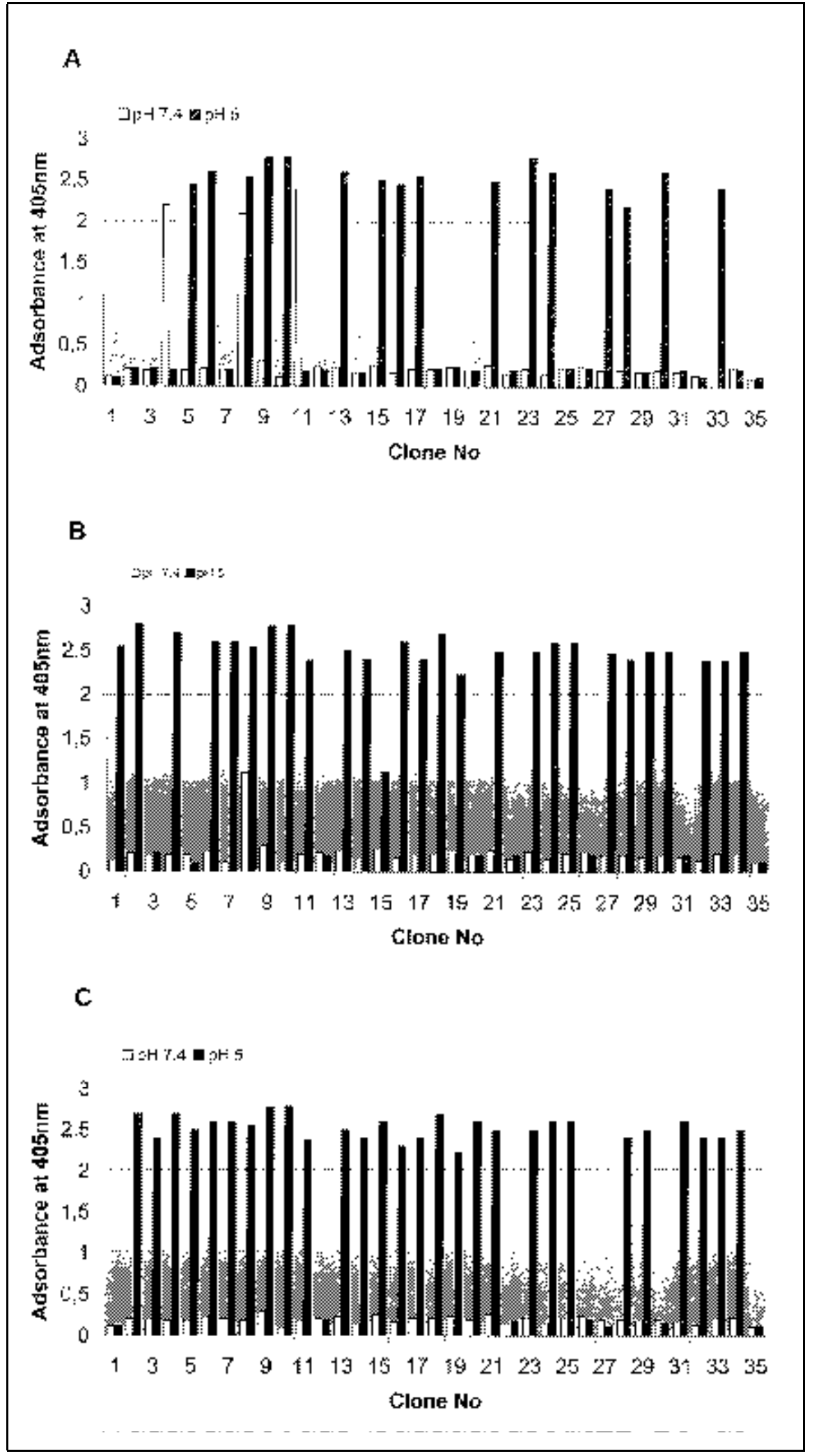

Figure 4. CM-ELISA with phage antibodies prepared from 34 clones picked after each round of selection on IMR5 cells under standard and stringent conditions. Binding of monoclonal phage antibodies were tested on IMR5 cell membranes after one (A), two (B), and three (C) rounds of selection. Binding of anti- $\mathrm{G}_{2}$ phage antibodies were visualized via peroxidase-conjugated anti-M13 antibody. Clone identification corresponds to insert analysis depicted in Figure 3G. Well 35, helper phage control. 


\section{Research Report}

Table 1. Enrichment of Anti- $\mathrm{G}_{\mathrm{D} 2}$ Phage Antibodies by Panning as Determined by Colony Number under Standard and Stringent Washing Conditions

\begin{tabular}{|lccc|}
\hline & Round & Input No. & Output No. \\
\hline Stringent panning $(\mathrm{pH} 5.0)$ & 1 & $1.3 \times 10^{10}$ & $2.3 \times 10^{4}$ \\
& 2 & $1.3 \times 10^{10}$ & $8.5 \times 10^{6}$ \\
& 3 & $1.3 \times 10^{10}$ & $9.6 \times 10^{6}$ \\
Standard panning $(\mathrm{pH} 7.4)$ & 1 & $1.3 \times 10^{10}$ & $1.9 \times 10^{4}$ \\
& 2 & $1.3 \times 10^{10}$ & $2.0 \times 10^{4}$ \\
& 3 & $1.3 \times 10^{10}$ & $2.5 \times 10^{3}$ \\
\hline
\end{tabular}

$12 \%$ by lowering the $\mathrm{pH}$ of the washing buffer to $\mathrm{pH} 5.0$ by supplementing citric acid (Figure 3G). These results confirm that insert-free phages are specifically enriched under standard washing procedures and that adhesive interactions between nonspecific binding phages and the cell surface are modified by changes of the physiological conditions. Thirtyfour individual clones were analyzed for binding by monoclonal phage CMELISA after each round of selection, under both stringent and standard conditions (Figure 4). By washing at $\mathrm{pH}$ 5.0 , selected phages with binding activi- ty strongly increased. After the first selection 16 phage clones (47\%), after the second round of selection 26 phage clones $(76 \%)$, and after the third round of selection 28 phage clones $(82 \%)$ showed signals of $\mathrm{OD}_{405}$ greater than or equal to 2, compared to a background of approximately $\mathrm{OD}_{405} 0.2$. Under standard conditions ( $\mathrm{pH} 7.4$ ), only 3 out of 34 clones were positive by CM-ELISA after the first round of selection; after successive selections, no binding activity was detected. Seventy percent of the clones bound to tumor membrane fractions (Figure 4). The enrichment of a

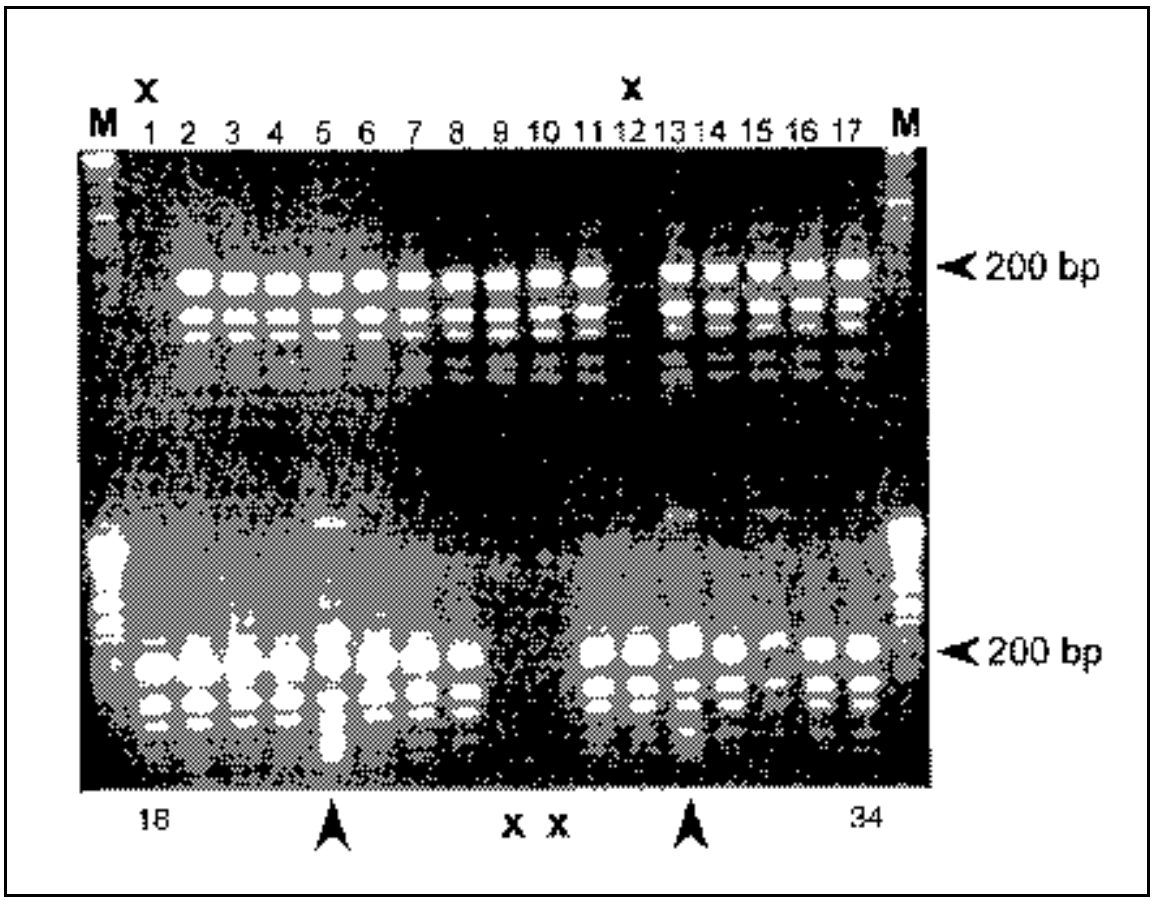

Figure 5. DNA fingerprinting of 34 clones picked after the third round of cell panning from the ch14.18-derived mini-library under stringent conditions ( $\mathrm{pH}$ 5.0). $\mathrm{PCR}$ products documented in Figure $3 \mathrm{G}$ were digested with $5 \mathrm{U} H a e I I I$ for $1 \mathrm{~h}$ at $37^{\circ} \mathrm{C}$. The restriction pattern was visualized after electrophoresis on a $3 \%$ agarose gel after ethidium bromide staining. M, molecular size standard (1-kb ladder). Clone identification is the same as in Figure 3G. Empty phages are marked by $\mathrm{x}$ and nonbinding phages by arrows.

specific $\mathrm{scFv}$ was analyzed by HaeIII restriction analysis of the 34 clones analyzed by monoclonal CM-ELISA. We found a direct correlation between fingerprint pattern and binding activity (Figure 5), which indicated successful enrichment of a neuroblastoma-specific phage antibody. The stringent washing conditions during the cell panning procedure used in this study significantly increased the quality of selected library by minimizing the amount of insert-free phages. A functional anti- $\mathrm{G}_{2}$ clone was isolated from a ch14.18-derived $\mathrm{scFv}$ mini-library by selection on the neuroblastoma cell line IMR5. The disialoganglioside $\mathrm{G}_{\mathrm{D} 2}$, expressed on almost all neuroblastoma cells (37) and on a significant quantity of melanoma cells (7), but nearly absent from most of the normal tissues, represents an excellent target for immunotherapy $(11,13$, $29)$. Since $G_{D 2}$-positive cells were efficiently eliminated by chemically linked immunotoxins (31), the selected $\mathrm{scFv}$ is currently being used for the construction of a new recombinant immunotoxin. In conclusion, we demonstrated that $\mathrm{scFv}$-free phage antibodies could be reduced significantly by stringent washing procedures during selection on target cells. Using this optimized washing protocol and screening with the established CM-ELISA, we were able to document the enrichment of a phage antibody directed against the neuroblastoma antigen $\mathrm{G}_{\mathrm{D} 2}$. This new procedure will be very useful for the selection of antibody fragments from phage display libraries on cellular surfaces.

\section{ACKNOWLEDGMENTS}

Supported in part by Deutsche Krebshilfe 70-2101-En 3.

\section{REFERENCES}

1.Ames, R.S., M.A. Tornetta, L.J. McMillan, K.F. Kaiser, S.D. Holmes, E. Appelbaum, D.M. Cusimano, T.W. Theisen, M.S. Gross, and C.S. Jones. 1995. Neutralizing murine monoclonal antibodies to human IL-5 isolated from hybridomas and a filamentous phage $\mathrm{Fab}$ display library. J. Immunol. 154:6355-6364.

2.Barth, S., M. Huhn, B. Matthey, A. Klimka, S. Tawadros, R. Schnell, V. Diehl, and A. Engert. 2000. Ki-4(scFv)-ETA, a new recombinant anti-CD30 immunotoxin with 
highly specific cytotoxic activity against disseminated Hodgkin tumors in SCID mice. Blood 95:3909-3914.

3.Berdichevsky, Y., E. Ben-Zeev, R. Lamed, and I. Benhar. 1999. Phage display of a cellulose binding domain from Clostridium thermocellum and its application as a tool for antibody engineering. J. Immunol. Methods 228:151-162.

4.Cai, X. and A. Garen. 1995. Anti-melanoma antibodies from melanoma patients immunized with genetically modified autologous tumor cells: selection of specific antibodies from single-chain $\mathrm{Fv}$ fusion phage libraries Proc. Natl. Acad. Sci. USA 92:6537-6541.

5.Cai, X. and A. Garen. 1997. Comparison of fusion phage libraries displaying VH or single-chain Fv antibody fragments derived from the antibody repertoire of a vaccinated melanoma patient as a source of melanoma-specific targeting molecules. Proc. Natl. Acad. Sci. USA 94:9261-9266.

6.Carroll, W.L., E. Mendel, and S. Levy. 1988. Hybridoma fusion cell lines contain an aberrant kappa transcript. Mol. Immunol. 25:991995.

7.Cheresh, D.A., J.R. Harper, G. Schulz, and R.A. Reisfeld. 1984. Localization of the gangliosides GD2 and GD3 in adhesion plaques and on the surface of human melanoma cells Proc. Natl. Acad. Sci. USA 81:5767-5771.

8.Courtney, B.C., K.C. Williams, and J.J. Schlager. 1995. A phage display vector with improved stability, applicability and ease of manipulation. Gene 165:139-140.

9.de Bruin, R., K. Spelt, J. Mol, R. Koes, and F. Quattrocchio. 1999. Selection of highaffinity phage antibodies from phage display libraries. Nat. Biotechnol. 17:397-399.

10.Dziegiel, M., L.K. Nielsen, P.S. Andersen, A. Blancher, E. Dickmeiss, and J. Engberg. 1995. Phage display used for gene cloning of human recombinant antibody against the erythrocyte surface antigen D. J. Immunol. Methods 182:7-19.

11.Fukuda, M., K. Horibe, and K. Furukawa. 1998. Enhancement of in vitro and in vivo anti-tumor activity of anti-GD2 monoclonal antibody 220-51 against human neuroblastoma by granulocyte-macrophage colony-stimulating factor and granulocyte colony-stimulating factor. Int. J. Mol. Med. 2:471-475.

12.Gillies, S.D., K.M. Lo, and J. Wesolowski. 1989. High-level expression of chimeric antibodies using adapted cDNA variable region cassettes. J. Immunol. Methods 125:191-202.

13.Gottstein, C., G. Schon, S. Tawadros, D. Kube, U.C. Wargalla-Plate, M.L. Hansmann, H.H. Wacker, F. Berthold, V. Diehl, and A. Engert. 1994. Antidisialoganglioside ricin A-chain immunotoxins show potent antitumor effects in vitro and in a disseminated human neuroblastoma severe combined im munodeficiency mouse model. Cancer Res. 54:6186-6193

14.Griffiths, A.D., M. Malmqvist, J.D. Marks, J.M. Bye, M.J. Embleton, J. McCafferty, M. Baier, K.P. Holliger, B.D. Gorick, and N.C. Hughes-Jones. 1993. Human anti-self antibodies with high specificity from phage display libraries. EMBO J. 12:725-734.

15.Hoogenboom, H.R. 1997. Designing and op- timizing library selection strategies for generating high-affinity antibodies. Trends Biotechnol. 15:62-70.

16.Hoogenboom, H.R., A.P. de Bruine, S.E. Hufton, R.M. Hoet, J.W. Arends, and R.C. Roovers. 1998. Antibody phage display technology and its applications. Immunotechnology $4: 1-20$.

17.Hoogenboom, H.R., J.D. Marks, A.D. Griffiths, and G. Winter. 1992. Building antibodies from their genes. Immunol. Rev. 130:4168.

18.Johnson, G. and T.T. Wu. 2000. Kabat Database and its applications: 30 years after the first variability plot. Nucleic Acids Res. 28:214-218.

19.Kapp, U., J. Wolf, C. von Kalle, S. Tawadros, A. Rottgen, A. Engert, C. Fonatsch, H. Stein, and V. Diehl. 1992. Preliminary report: growth of Hodgkin's lymphoma derived cells in immune compromised mice. Ann. Oncol. (3 Suppl.) 4:21-23.

20.Klimka, A., S. Barth, B. Matthey, R.C. Roovers, H. Lemke, H. Hansen, J.W. Arends, V. Diehl, H.R. Hoogenboom, and A. Engert. 1999. An anti-CD30 single-chain Fv selected by phage display and fused to $\mathrm{Pseu}$ domonas exotoxin $\mathrm{A}(\mathrm{Ki}-4(\mathrm{scFv})-\mathrm{ETA})$ is a potent immunotoxin against a Hodgkin-derived cell line. Br. J. Cancer 80:1214-1222.

21.Klimka, A., B. Matthey, R. Roovers, S. Barth, F. Bot, J.W. Arends, A. Engert, and H.R. Hoogenboom. 2000. Human anti-CD30 recombinant antibodies by guided phage antibody library selection and cell panning. Brit. J. Cancer 83:252-260.

22.Krebber, A., S. Bornhauser, J. Burmester, A. Honegger, J. Willuda, H.R. Bosshard, and A. Pluckthun. 1997. Reliable cloning of functional antibody variable domains from hybridomas and spleen cell repertoires em ploying a reengineered phage display system. J. Immunol. Methods 201:35-55.

23.Kupsch, J., N. Tidman, J. Bishop, I. McK ay, I. Leigh, and J. Crowe. 1995. Generation and selection of monoclonal antibodies, single-chain Fv and antibody fusion phage specific for human melanoma-associated antigens. Melanoma Res. 5:403-411.

24.Lin, J., K. Yanase, A. Rutgers, M.P. Madaio, and K.E. Meyers. 1999. Selection of specific phage from display libraries: monoclonal antibody against VCS M13 helper phage coat protein III (gIIIp). Hybridoma 18:257-261.

25.Lu, J. and S.R. Sloan. 1999. An alternating selection strategy for cloning phage display antibodies. J. Immunol. Methods 228:109119.

26.Marks, J.D., H.R. Hoogenboom, T.P. Bonnert, J. McCafferty, A.D. Griffiths, and G. Winter. 1991. By-passing immunization. Human antibodies from V-gene libraries displayed on phage. J. Mol. Biol. 222:581-597.

27.Matthey, B., A. Engert, A. Klimka, V. Diehl, and S. Barth. 1999. A new series of pET-derived vectors for high efficiency expression of Pseudomonas exotoxin-based fusion proteins. Gene 229:145-153.

28.McCafferty, J., K.J. Fitzgerald, J. Earnshaw, D.J. Chiswell, J. Link, R. Smith, and J. Kenten. 1994. Selection and rapid purifica- tion of murine antibody fragments that bind a transition-state analog by phage display. Appl. Biochem. Biotechnol. 47:157-171.

29.Mueller, B.M., C.A. Romerdahl, S.D. Gillies, and R.A. Reisfeld. 1990. Enhancement of antibody-dependent cytotoxicity with a chimeric anti-GD2 antibody. J. Immunol. 144:1382-1386.

30.Mutuberria, R., H.R. Hoogenboom, E. van der Linden, A.P. de Bruine, and R.C. Roovers. 1999. Model systems to study the parameters determining the success of phage antibody selections on complex antigens. J. Immunol. Methods 231:65-81.

31.Pastan, I., M.C. Willingham, and D.J. FitzGerald. 1986. Immunotoxins. Cell 47:641648.

32.Rakonjac, J., G. Jovanovic, and P. Model. 1997. Filamentous phage infection mediated gene expression: construction and propagation of the gIII deletion mutant helper phage R408d3. Gene 198:99-103.

33.Seehaus, T., F. Breitling, S. Dubel, I. Klew inghaus, and M. Little. 1992. A vector for the removal of deletion mutants from antibody libraries. Gene 114:235-237.

34.Valadon, P. and M.D. Scharff. 1996. Enhancement of ELISAs for screening peptides in epitope phage display libraries. J. Immunol. Methods 197:171-179.

35.Watters, J.M., P. Telleman, and R.P. Junghans. 1997. An optimized method for cellbased phage display panning. Immunotechnology 3:21-29.

36.Winter, G., A.D. Griffiths, R.E. Hawkins, and H.R. Hoogenboom. 1994. Making antibodies by phage display technology. Annu. Rev. Immunol. 12:433-455.

37.Wu, Z.L., E. Schwartz, R. Seeger, and S. Ladisch. 1986. Expression of G2 ganglioside by untreated primary human neuroblastomas. Cancer Res. 46:440-443.

Received 5 April 2000; accepted 7 August 2000.

Address correspondence to:

Dr. Dr. Stefan Barth

Klinik I fuer Innere Medizin der Universitaet zu Koeln

Labor fuer Immuntherapie

LFI, E4, R056

Joseph-Stelzmann-Str. 9

D-50931 KOELN, Germany

e-mail: stefan.barth@uni-koeln.de 